\title{
The effect of interstimulus procedures on salt taste thresholds
}

\author{
M. O'MAHONY and L. GODMAN \\ Bristol University, 8-10 Berkeley Square, Clifton, Bristol 8, England
}

\begin{abstract}
$\mathrm{NaCl}$ detection and recognition thresholds were measured with and without a prior artificial raising of the level of adaptation by a molar salt mouthrinse. In both cases, it was found that an interstimulus procedure involving water mouthrinses yielded lower thresholds than a procedure with no rinses. These results were seen to be predicted from adaptation level changes. The literature was seen to confirm these results, while difficulties in threshold measurement were discussed.
\end{abstract}

Hahn (1934) noted that $\mathrm{NaCl}$ thresholds were determined by $\mathrm{NaCl}$-adapting concentrations; this study, as well as others later summarized by Hahn (1949), also extended the work to other taste stimuli. McBurney and Pfaffmann (1963) showed that $\mathrm{NaCl}$ thresholds, measured in situ, were related to the relatively weak salivary $\mathrm{Na}$ content in the same way that $\mathrm{NaCl}$ thresholds, measured with a flow procedure, were related to the adapting solution concentration; this confirmed an earlier suggestion by Richter and MacLean (1939). Békésy (1965), using a semiautomatic gustometer, later demonstrated how adaptation caused a continuous shift of $\mathrm{NaCl}$ threshold.

There being no generally accepted policy on the length of rest interval required between tastings or on the use of mouthrinses, O'Mahony (1972a) investigated the common interstimulus procedures and found they were insufficient to remove $\mathrm{NaCl}$ residuals from prior tastings. Furthermore, because of gustatory adaptation, these residuals caused sensitivity drifts (O'Mahony, 1972b). It is expected, then, that a more efficient interstimulus procedure, like mouthrinsing, would maintain a lower general level of adaptation, yielding lower in situ thresholds, than an equivalent procedure that did not involve rinsing.

As with many taste stimuli, the detection of $\mathrm{NaCl}$ in water is traditionally described by two thresholds: the recognition threshold, where the salty taste appears, and the detection threshold, where the presence of $\mathrm{NaCl}$ is noticed although it is not described as salty. Richter and MacLean (1939) listed early studies, criticizing them for not distinguishing between the two; other early studies (Camerer, 1885; Blakeslee \&Salmon, 1935) and some more recent (Schutz \& Pilgrim, 1957; Krut, Perrin, \& Bronte-Stewart, 1961; Jackson, 1967) can be added to their list. However, there is more than one sensation change below the recognition threshold (O'Mahony, 1973), any one of which could be taken as the criterion for detection. This means that any comparison of thresholds between $\mathrm{Ss}$ is susceptible to criterion variation. Herein lics the advantage of criterion-free signal detection measures of sensitivity (Green \& Swets, 1966). Given criterion variation in the definition of detection, and to some extent recognition, any comparison of the effects of interstimulus procedure must be made within Ss, so that there is more chance of constant criteria for different conditions. The present study used such a design to examine the effects of a mouthrinsing interstimulus procedure on detection and recognition thresholds.

\section{EXPERIMENT I}

Experiment I was split into a preliminary and a main experiment, which was performed approximately 18 months later.

\section{Preliminary Experiment Procedure}

Using two Ss, students at Bristol University, M.Q. (male, 29 years) and B.T. (female, 22 years), the $\mathrm{NaCl}$ detection threshold was found by the method of constant stimuli in four conditions: (1) A $10-\mathrm{ml}$ sample of each test solution was tasted immediately following a 15-sec, $10-\mathrm{ml}$ mouthrinse with $1 \mathrm{M} \mathrm{NaCl}$ solution. (2) As for Condition 1, except that an approximately $50-\mathrm{ml}, 15-\mathrm{sec}$ tapwater mouthrinse was interspersed between the $1 \mathrm{M} \mathrm{NaCl}$ and the test solution. (3) As for Condition 2, except that a 15-sec period of vigorous sucking ending in expectoration of saliva was interspersed between expectoration of the tapwater mouthrinse and the test solution. (4) As for Condition 2, except that Ss expectorated saliva once immediately after expectorating the tapwater mouthrinse.

Test solution concentrations used were: for Condition 1, $300-950 \mathrm{mM}$ in $50-\mathrm{mM}$ steps, and for Conditions 2, 3, and 4, $70-150 \mathrm{mM}$ in 5-mM steps. The $\mathrm{E}$ used trial and error to establish the actual range of concentrations to be presented to each $S$; having established this, each concentration in the range was presented 10 times. The ranges chosen for Conditions $1,2,3$, and 4 for each $S$ were: M.Q., $500-850 \mathrm{mM}, 100-150 \mathrm{mM}, 100-140 \mathrm{mM}, 100$ $140 \mathrm{mM}$; and B.T., $300-500 \mathrm{mM}, 90-130 \mathrm{mM}, \quad 70-120 \mathrm{mM}$, $70-120 \mathrm{mM}$, respectively.

Test solutions were sipped from $10-\mathrm{ml}$ beakers. Test solutions 
and mouthrinses were expectorated. Solutions were made up with Analar grade $\mathrm{NaCl}$ in distilled water and presented at room temperature $\left(\cong 20^{\circ} \mathrm{C}\right)$.

All four conditions were used simultaneously to eliminate effects of practice, fatigue, and criterion drift. A pilot study showed that an interstimulus procedure of two tapwater mouthrinses followed by a $1-$ min rest, after each test solution and before each $1 \mathrm{M} \mathrm{NaCl}$ mouthrinse, was enough to eliminate sensitivity drifts. Rest periods and session lengths $\left(1-4 \frac{1}{2} \mathrm{~h}\right)$ were determined by S's convenience and motivation; M.Q. took a total of 12 sessions (total experimental time, $19 \mathrm{~h})$ and B.T., 8 sessions $(20 \mathrm{~h})$.

\section{Main Experiment Procedure}

The procedure was the same as for the preliminary experiment except that Condition 4 was omitted. Five Ss, staff and students at Bristol University, were used: M.Q. (male, 31 years), C.O. (male, 25 years), M.W. (male, 19 years), H.L. and E.W. (females, 20 years).

The test solution concentrations used were: Condition 1, $50-950 \mathrm{mM}$ in 50-mM steps, and Conditions 2 and 3, 35-150 mM in 5-mM steps. The ranges chosen for Conditions 1,2, and 3 for each $S$ were: M.Q., 450-650 mM, 85-115 mM, 70-125 mM; C.O., 100-400 mM, 40-100 mM, 40-110 mM; M.W., $550-800 \mathrm{mM}$, 90-150 mM, 95.115 mM; H.L., $200-400 \mathrm{mM}, \quad 50-85 \mathrm{mM}$, 45-65 mM; E.W., 200-600 mM, 100-150 mM, 80-110 mM, respectively.

An interstimulus interval of $2 \mathrm{~min}$, during which two tapwater mouthrinses were taken, was found to be satisfactory. Experimental session lengths $\left(20 \min -4 \frac{1}{2} \mathrm{~h}\right.$ ) were again determined by $\mathrm{S} ; \mathrm{M} . \mathrm{Q}$. took a total of 5 sessions (total experimental time, $121 / 2$ h); C.O., 20 sessions ( $22 \mathrm{~h})$; M.W., 9 sessions $\left(8 \frac{1 / 2}{h}\right.$ ); H.L., 3 sessions $(7 \mathrm{~h})$, and $E$. W., 10 sessions $(17 \mathrm{~h})$.

\section{Results}

Threholds estimated by eye, using linearprobability plots, are shown in Table 1; error terms were computed from maximum and minimum slopes. Very high thresholds for Condition 1 showed that a molar mouthrinse considerably elevated the threshold. Condition 2 yielded much lower values (no overlap of error terms), showing the potency of rinsing as an interstimulus procedure.

Thresholds were lower in Condition 3 than in Condition 2 (except for C.O.); for E.W., B.T., and M.Q. (preliminary experiment), there was no overlap of error terms. In Condition 4, thresholds were not higher than in Condition 2. This is all strong evidence that further expectoration after a mouthrinse did not result in a higher threshold, showing that the low threshold in Condition 2 was not due to a tapwater residual resting on the tongue.

M.Q. was used for the preliminary and main experiment; in the main experiment, his thresholds were lower, probably due to different criteria, but the trend between conditions was the same.

Ss reported that criterion changes were the main source of variance. Ss reported that only in Condition 1 was there ever a salt taste in the mouth when Ss sipped the test solution; this means that threshold elevation was partially due to masking as well as raising the level of adaptation. The salt taste left in the mouth after adapting to the molar $\mathrm{NaCl}$
Table 1

$\mathrm{NaCl}$ Detection Thresholds (in Millimolars) Measured After a Molar $\mathrm{NaCl}$ Mouthrinse in Four Conditions

\begin{tabular}{crrrr} 
& \multicolumn{4}{c}{ Conditions } \\
\cline { 2 - 5 } S & \multicolumn{1}{c}{1} & \multicolumn{1}{c}{3} & \multicolumn{1}{c}{4} \\
\hline Preliminary & Experiment & & & \\
M. Q. & $720( \pm 30)$ & $120( \pm 7)$ & $108( \pm 2)$ & $120( \pm 7)$ \\
B. T. & $380( \pm 20)$ & $117( \pm 3)$ & $92( \pm 3)$ & $92( \pm 3)$ \\
Main Experiment & & & \\
E. W. & $420( \pm 40)$ & $129( \pm 9)$ & $95( \pm 1)$ & \\
M. Q. & $530( \pm 30)$ & $96( \pm 4)$ & $87( \pm 7)$ & \\
H. L. & $300( \pm 5)$ & $65( \pm 9)$ & $59( \pm 3)$ & \\
M. W. & $580( \pm 90)$ & $119( \pm 16)$ & $107( \pm 3)$ & \\
C. O. & $190( \pm 40)$ & $67( \pm 4)$ & $72( \pm 2)$ & \\
\hline
\end{tabular}

solution indicates that adaptation was not complete during the $15-\mathrm{sec}$ period. This also tends to be supported by the fact that thresholds in Condition 1 were well below $1 \mathrm{M}$. Complete adaptation has been reported for lower $\mathrm{NaCl}$ concentrations: $100 \mathrm{mM}$ within $40 \mathrm{sec}$ (Bartoshuk, 1968), $150 \mathrm{mM}$ in $50-54 \mathrm{sec}$ (Bujas, 1953), $200 \mathrm{mM}$ in 79-90 sec (Borg, Diamant, \& Zotterman, 1970), and $360 \mathrm{mM}$ in $3 \mathrm{~min}$, (Meiselman, 1968), though for only one of four Ss. If attempted complete adaptation had been the aim of this experiment, however, a flow procedure with a far longer adaptation time would have been used.

\section{EXPERIMENT II}

\section{Procedure}

In this experiment, $\mathrm{NaCl}$ detection and recognition thresholds were measured for 20 naive $\mathrm{Ss}$, male and female students at Bristol University, aged 19-30 years, without any prior artificial raising of the adaptation level. The commonly used ascending series method was used in this case; in such a procedure, $\mathrm{NaCl}$ solutions of increasing concentration are presented to $S$ until he can identify the salt, descending series not being used to avoid masking.

Ten milliliters of test solution were sipped from $10-\mathrm{ml}$ beakers at 15-sec intervals, held in the mouth approximately $3 \mathrm{sec}$ and expectorated. Ss were tested under two conditions; in one condition, an approximately $50-\mathrm{ml}$ tapwater mouthrinse was taken after expectoration of the test solution and was itself expectorated immediately prior to sipping the'next test solution. In the second condition, no mouthrinse was used. The two conditions were tested with 1 to 3 tapwater mouthrinses and approximately $1 / 2 \mathrm{~h}$ rest between, and the order of conditions was counterbalanced. The ascending series test solutions were distilled water, 1, 5, 10, 15, 20, 40,60 , and $80 \mathrm{mM} \mathrm{NaCl}$; each series was presented three times in each condition. All solutions were of the same purity and temperature as in Experiment I. All solutions and mouthrinses were expectorated.

\section{Results}

Mean and median detection and recognition thresholds for the $20 \mathrm{Ss}$ are given in Table 2. Despite considerable individual differences, the mouthrinsing interstimulus procedure yielded significantly lower mean detection and recognition thresholds $(\mathrm{p}<.01$, Wilcoxon, one-tailed), demonstrating how mouthrinses maintain a lower level of adaptation. The order 
Table 2

Ascending Series $\mathrm{NaCl}$ Detection and Recognition Thresholds Measured With and Without Tap Water Mouthrinsing $(N=20)$

\begin{tabular}{llcc}
\hline & & \multicolumn{2}{c}{ Threshold (mM) } \\
\cline { 3 - 4 } $\begin{array}{l}\text { Interstimulus } \\
\text { Procedure }\end{array}$ & & Detection & Recognition \\
\hline & Mean & 15.4 & 26.8 \\
15-Sec Rest & Median & 13.3 & 24.1 \\
& Range & $2.3-36.6$ & $8.3-66.6$ \\
$15-S e c$ & Mean & 8.6 & 17.9 \\
Tap Water & Median & 7.6 & 13.3 \\
Mouthrinse & Range & $1.0-23.3$ & $3.6-60.0$ \\
\hline
\end{tabular}

of "mouthrinse" vs "no-mouthrinse" conditions was counterbalanced, though Ss who had the latter condition first, reported some confusion due to its greater difficulty. All but one of the 4 Ss whose thresholds were not in the direction predicted, had the "mouthrinse" condition first; 2 Ss recorded ties. Atypical results were probably due to lack of skill in maintaining a constant criterion.

\section{DISCUSSION}

The present study demonstrated directly how mouthrinsing, by maintaining a lower level of adaptation, yielded lower detection and recognition thresholds. This occurred both with and without an artificial raising of the level of adaptation by a molar $\mathrm{NaCl}$ rinse, although the effect was more pronounced in the former case.

These results were also predicted by McBurney and Ptaffman (1963) and Dallenbach and Dallenbach (1943), who themselves found lower thresholds (probably detection) with mouthrinses. Richter and ascending series presentation than for their Choice Methods 1 and 2, which involved frequent tasting of distilled water, having the same effect as mouthrinsing. Unfortunately, only these three studies yield a direct comparison for the same authors, while MacLean (1939) found higher thresholds for

only McBurney and Pfaffmann's may have used a within-Ss comparison. However, they all confirm the current findings.

Further comparison with the literature yielded a general contirmation, despite the many methodological variables. Ascending series thresholds tended to be lower when mouthrinsing was used, as did they also when comparison procedures, involving frequent tasting of water, were used. Many studies were precise in defining whether they studied detection or recognition, and their results are given in Tables 3,4 , and 5. Others, which were not so precise in their definitions but were still open to reasonable interpretation, will be discussed along with tabulated studies; only Mayer's (1927) and Irvin and Goetzl's (1952) studies gave insufficient methodological details for comparison. For the purpose of this discussion, all concentration values will be expressed as mM, conversions being performed when necessary.

Turning first to ascending series presentation, detection thresholds are given in Table 3. Despite considerable variation, mean values were lower with mouthrinsing than without. Smaller stimulus samples gave higher thresholds, and this is probably due, certainly with Richter and MacLean's results, to the known relationship between threshold and tongue area stimulated (McBurney, 1969). As already mentioned, Dallenbach and Dallenbach's mouthrinsing values $(5.1,6.8 \mathrm{mM})$ were lower than their no-mouthrinsing values $(38.8,39.6,47.4 \mathrm{mM})$, as were McBurney and Pfaffmann's $(2.2 \mathrm{mM}$ vs $8.6 \mathrm{mM}$ ). Further no-mouthrinsing values found by the latter authors yielded values ranging 3.4-22 mM. Kahn (1951), using no mouthrinses, found very high detection thresholds (21.4-42.8 $\mathrm{mM})$, but these values can be discounted because only three test solutions were used. Meyer (1952), using the method of limits and distilled water mouthrinses between tastings, obtained a high detection threshold (10-19 mM), probably because of the small stimulus quantities

Table 3

Detection Thresholds for NaCl Found With an Ascending Series Presentation for Rinsing and Nonrinsing Interstimulus Procedures

\begin{tabular}{|c|c|c|c|c|c|c|}
\hline \multirow{3}{*}{$\begin{array}{l}\text { Authors } \\
\text { Richter \& MacLean, } 1939\end{array}$} & \multirow{3}{*}{$\frac{\text { Ss }}{17}$} & \multirow{3}{*}{$\frac{\begin{array}{l}\text { Stimulus } \\
\text { Quantity }\end{array}}{3 \text { Drops }}$} & \multicolumn{4}{|c|}{ Detection Thresholds (mM) } \\
\hline & & & \multicolumn{2}{|c|}{ Mouthrinsing } & \multicolumn{2}{|c|}{ No Mouthrinsing } \\
\hline & & & & & $\begin{array}{l}\text { Mean } \\
\text { Range }\end{array}$ & $\begin{array}{l}23.1 \\
7.7-38.4\end{array}$ \\
\hline Mefferd \& Wieland, 1968 & 3 & $5 \mathrm{ml}$ & & & Values & $22.8,27.3,29.5$ \\
\hline Fabian \& Blum, 1943 & 15 & $5 \mathrm{ml}$ & & & Mean & 11 \\
\hline Richter \& MacLean, 1939 & 24 & $10 \mathrm{ml}$ & & & $\begin{array}{l}\text { Mean } \\
\text { Range }\end{array}$ & $\begin{array}{l}8.0 \\
2.6-25.6\end{array}$ \\
\hline O'Mahony \& Godman & 20 & $10 \mathrm{ml}$ & $\begin{array}{l}\text { Mean } \\
\text { Range } \\
\text { Median }\end{array}$ & $\begin{array}{l}8.6 \\
1.0-23.3 \\
7.6\end{array}$ & $\begin{array}{l}\text { Mean } \\
\text { Range } \\
\text { Median }\end{array}$ & $\begin{array}{l}15.4 \\
2.3-36.6 \\
13.3\end{array}$ \\
\hline Finkelstein \& Pippitt, 1958 & 10 & $5-10 \mathrm{ml}$ & $\begin{array}{l}\text { Tap Wa } \\
\text { Mean } \\
\text { Distilled }\end{array}$ & $\begin{array}{l}\text { inse } \\
7.4^{*} \\
\text { er Rinse }\end{array}$ & & \\
\hline
\end{tabular}


Table 4

Recognition Thresholds for NaCl Found With an Ascending Series Presentation for Rinsing and Nonrinsing Interstimulus Procedures

\begin{tabular}{|c|c|c|c|c|c|}
\hline \multirow{3}{*}{$\frac{\text { Authors }}{\text { Richter \& MacLean, } 1939}$} & \multirow{3}{*}{$\frac{\text { Ss }}{17}$} & \multirow{3}{*}{$\begin{array}{l}\begin{array}{l}\text { Stimulus } \\
\text { Quantity }\end{array} \\
3 \text { Drops }\end{array}$} & \multicolumn{3}{|c|}{ Recognition Thresholds (mM) } \\
\hline & & & Mouthrinsing & \multicolumn{2}{|c|}{ No Mouthrinsing } \\
\hline & & & & $\begin{array}{l}\text { Mean } \\
\text { Range }\end{array}$ & $\begin{array}{l}32.8 \\
20.5-59.9\end{array}$ \\
\hline Fabian \& Blum, 1943 & 15 & $5 \mathrm{ml}$ & & Mean & 39 \\
\hline Mefferd \& Wieland, 1968 & 3 & $5 \mathrm{ml}$ & & Values & $25.4,37.6,39.0$ \\
\hline Richter \& MacLean, 1939 & 24 & $10 \mathrm{ml}$ & & $\begin{array}{l}\text { Mean } \\
\text { Range }\end{array}$ & $\begin{array}{l}28.6 \\
6.8-68.4\end{array}$ \\
\hline O'Mahony \& Godman & 20 & $10 \mathrm{ml}$ & $\begin{array}{lc}\text { Mean } & 17.9 \\
\text { Range } & 3.6-60.0 \\
\text { Median } & 13.3 \\
\text { Tap Water } & \text { Rinse }\end{array}$ & $\begin{array}{l}\text { Mean } \\
\text { Range } \\
\text { Median }\end{array}$ & $\begin{array}{l}26.8 \\
8.3-66.6 \\
24.1\end{array}$ \\
\hline Mackey \& Jones, 1954 & 22 & & & $\begin{array}{l}\text { Mean } \\
\text { Range } \\
\text { Median }\end{array}$ & $\begin{array}{l}19.9 \\
3.3-75 \\
13.3\end{array}$ \\
\hline $\begin{array}{l}\text { Mosel \& Kantrowitz, } 1952 \\
\text { Finkelstein \& Pippitt, } 1958\end{array}$ & $\begin{array}{r}4 \\
10\end{array}$ & $\begin{array}{l}15 \mathrm{ml} \\
5-10 \mathrm{ml}\end{array}$ & $\begin{array}{l}\text { Mean } 10.0^{*} \\
\text { Distilled Water Rinse }\end{array}$ & Mean & 7.5 \\
\hline $\begin{array}{l}\text { Yensen, } 1958,1959 \mathrm{a}, \mathrm{b}, \mathrm{c}, 1964 \\
\text { Maga \& Lorenz, } 1972\end{array}$ & $\begin{array}{l}2-4 \\
6\end{array}$ & $\begin{array}{l}8-10 \mathrm{ml} \\
20 \mathrm{ml}\end{array}$ & $\begin{array}{ll}\text { Range } & 1.5-4.3 \\
\text { Mean } & 0.8 \\
\text { Distilled } & \text { Water } \\
\text { Rinse }\end{array}$ & & \\
\hline
\end{tabular}

*No units, probably millimolars

used ( 1 drop) and perhaps because of masking effects in the descending series or interference with mouthrinsing effects by his practice of drying the tongue with blotting paper.

Ascending series recognition thresholds are given in Table 4, and again mouthrinsing tended to give lower values, as did larger stimulus quantities. Yensen's values-2.2-3.4 $\mathrm{mM}$ (Yensen, 1958, 1959b), 1.9$3.8 \mathrm{mM}$ (Yensen, 1959a), 1.5-4.3 mM (Yensen, $1959 \mathrm{c}$ ), and 1.7-3.4 $\mathrm{mM}$ (Yensen, 1964)--were grouped together in the table and are seen to be very low, comparable even to detection thresholds. This may have been due to the many readings taken with practiced Ss, his use of small stimulus increments, and the stringent mouthrinsing procedure employed. Mosel and Kantrowitz (1952) and Maga and Lorenz (1972) also gave comparably low values. For the latter. this may be because Ss indulged in excessive rinsing or used a detection criterion, while for the former, large stimulus quantities, few Ss, and repeated determinations may be causal factors. The study of Mackey and Jones (1954) did not mention the use of rinses, and it is assumed that they did not use them.

All recognition studies, not tabulated, used mouthrinses. King (1937), Knowles and Johnson (1941), and Hopkins (1946) found high values (respective medians, 25.6, 19.9, $19.2 \mathrm{mM}$ ), compar-

Table 5

Detection and Recognition Thresholds for NaCl Found With Procedures Based on Richter \& MacLean's Choice Method No. 2

\begin{tabular}{|c|c|c|c|c|c|c|}
\hline \multirow{3}{*}{$\frac{\text { Authors }}{\text { Richter \& MacLean, } 1939}$} & \multirow{3}{*}{$\frac{\text { Ss }}{53}$} & \multicolumn{4}{|c|}{ Threshold Values (mM) } & \multirow{2}{*}{$\begin{array}{l}\text { Methodological Deviations } \\
\text { from Choice Method No. } 2 \\
\text { and Other Notes }\end{array}$} \\
\hline & & \multicolumn{2}{|r|}{ Detection } & \multicolumn{2}{|c|}{ Recognition } & \\
\hline & & $\begin{array}{l}\text { Mean } \\
\text { Range }\end{array}$ & $\begin{array}{l}2.7 \\
1.2-10.3\end{array}$ & $\begin{array}{l}\text { Mean } \\
\text { Range }\end{array}$ & $\begin{array}{l}14.9 \\
3.4-42.8\end{array}$ & \\
\hline Janowitz \& Grossman, 1949 & 9 & & & Means & $11.1,11.6,10.9$ & $\begin{array}{l}\text { Means taken } 10: 30 \text { a.m., } 12 \\
\text { noon, and 2:00 p.m. }\end{array}$ \\
\hline Cooper, Bilash, \& Zubek, 1959 & 100 & Means & $\begin{array}{l}5.5,6.2,8.0 \\
21.0,17.2\end{array}$ & Means & $\begin{array}{l}21.1,15.6,18.8 \\
46.2,53.0\end{array}$ & $\begin{array}{l}\text { Samples aged 15-29, } 30-44 \text {, } \\
45-59,60-74,75-89\end{array}$ \\
\hline $\begin{array}{l}\text { Kapur, Collister, \& Fischer, } \\
1967\end{array}$ & 12 & Means & $22.4,22.0,23.6$ & Means & $44.3,44.5,41.7$ & $\begin{array}{l}\text { Three samples of denture } \\
\text { wearers }\end{array}$ \\
\hline Pangborn, 1959 & 8 & Means & $21,8,5$ & & & $\begin{array}{l}\text { Three mean control values, de- } \\
\text { creasing with practice }\end{array}$ \\
\hline Furchtgott \& Willingham, 1956 & 18 & Mean & 7.0 & & & Control value \\
\hline $\begin{array}{l}\text { Fallis, Lasagna, \& Tetreault, } \\
1962\end{array}$ & 20 & & & Mean & 9.7 & $\begin{array}{l}\text { Compare } \mathrm{NaCl} \text { solution with } \\
\text { three distilled water samples }\end{array}$ \\
\hline Topinka \& Sova, 1967 & 21 & & & Mean & 6.5 & $\begin{array}{l}\text { Compare } \mathrm{NaCl} \text { solution with } \\
\text { three distilled water samples }\end{array}$ \\
\hline $\begin{array}{l}\text { DeWardener \& Herxheimer, } \\
1957\end{array}$ & 2 & & & Ranges & $\begin{array}{l}1.7-13.7 \text { and } \\
1.3-5.1\end{array}$ & Control values \\
\hline
\end{tabular}


able to tabulated no-mouthrinsing values for the same stimulus quantity, $5 \mathrm{ml}$. The instructions in the latter two studies could account for this, because Ss were required to report only when they were positive of the taste and this could have raised S's criteria. Brown's (1914) value $(102.7 \mathrm{mM})$ was probably artificially high due to the small stimulus quantities used $(1 \mathrm{ml})$, while Ufland's (1928) and Hermel, Schonwetter, and Samueloff's (1970) high mean values (42.8 and $78.7 \mathrm{mM}$ ) were open to question because only three test stimuli were used; the value in the latter paper may not be reliable owing to confusion over concentration values.

The U.S. Department of Agriculture (1943) found large individual differences for recognition thresholds, using mouthrinsing for strong solutions, which fell into three ranges: 2.5-5.0, 7.5-20, and 25-100 mM. Most Ss fell in the medium range, comparable to values in Table 4 , but $25 \%$ were in the high and lower ranges. Such variation emphasizes the importance of the within-Ss design, in the present study, for examining the effects of mouthrinsing.

Finally, pair comparison methods can be considered. Table 5 shows threshold values found using Richter and MacLean's Choice Method 2, which involves ad lib pair comparisons with distilled water. Thresholds were often comparable to ascending series mouthrinsing values. An exception is the study of Kapur, Collister, and Fischer (1967), which yielded very high thresholds. The most likely explanation is that their Ss, being denture wearers, were elderly, and from Cooper, Bilash, and Zubek's (1959) results, it can be seen that thresholds rise with age.

Fallis, Lasagna, and Tetreault (1962) and Topinka and Sova (1967) used three distilled water samples instead of one and also incorporated mouthrinses; their thresholds can be seen to be predictably lower than other tabulated values. Comparable values $(7.4-8.9 \mathrm{mM})$ were obtained by Furchtgott and Fricdman (1960) using the same modified method; this suggests that they were measuring recognition, although this was not made clear. Anderson (1955) also obtained a comparably low recognition threshold $(9.2 \mathrm{mM})$, having modified the procedure by incorporating mouthrinses between tastings.

Although some of De Wardener and Herxheimer's (1957) recognition values were comparably high, they tended to be lower than other values in Table 5. This could be due to an element of detection in the threshold measurement and also to the effects of practice; Pangborn's (1959) results showed how comparable practice could reduce thresholds.

Further comparison methods occur in the literature. Richter and MacLean's Choice Method 1, utilizing only one tasting of each sample, yielded predictably higher threshold values. [detection 6.3
(1.2-13.7), recognition $13.6(5.1-51.3) \mathrm{mM}]$ than their Choice Method 2. The method is briefer and involves the tasting of fewer water samples; nevertheless, these values are comparable to ascending series mouthrinse values.

Also comparable are other pair comparison detection measures: Kelty and Mayer (1971), $11.1 \mathrm{mM}$, Frings (1948), $5.2 \mathrm{mM}$, and Renquist (1919), $10 \mathrm{mM}$. Schelling. Tetreault, Lasagna, and Davis's (1965) mean recognition threshold of $5.2 \mathrm{mM}$ was comparable to detection values; they reported, however, that in most cases the two coincided. Kelty and Mayer's recognition threshold $(27.4 \mathrm{mM})$, however, was higher than corresponding values in Table 4.

A widely used comparison method for measuring detection thresholds is the Harris-Kalmus test (Kalmus, 1971; Harris \& Kalmus, 1949), developed for the study of P.T.C. It involves sorting four equimolar $\mathrm{NaCl}$ solutions and four distilled water samples into two groups. Using this method, Wotman, Mandel, Thompson, and Laragh (1967) obtained a median threshold value of $13.7 \mathrm{mM}$, while moditications of the procedure incorporating mouthrinses gave comparable thresholds: 13.7 and $12 \mathrm{mM}$ (Wotman et al, 1964; Fischer, Griffin, \& Kaplan, 1963). The small effects of rinsing are not surprising as a lot of water tasting is involved in the procedure anyway.

The triangular testing methods (to distinguish one $\mathrm{NaCl}$ solution from two distilled water solutions) of Henkin and Solomon (1962) and Henkin, Gill, and Bartter (1963) yielded median detection thresholds of $12 \mathrm{mM}$. These were slightly higher than comparable ascending series values using mouthrinses, probably because of the small stimulus quantities used (1 drop). Triangular testing with larger stimulus quantities $(10 \mathrm{ml})$ yielded lower mean thresholds: 10.6 and $3.4 \mathrm{mM}$ (Hutchinson \& Shiller, 1968).

Harries (1973), with an ascending series presentation, provided distilled water for comparison. His mean detection threshold $(12.2 \mathrm{mM})$ is comparable to pair comparison and ascending series values without mouthrinsing while being predictably higher than those with mouthrinsing. Williams (1970) and Pangborn, Chrisp, and Bertolero (1970) both incorporated pair comparison in the method of constant stimuli. The latter provided water for rinsing but unexpectedly found higher detection thresholds (2-6 $\mathrm{mM}$ vs $1.5-3.7 \mathrm{mM}$ ). However, they used a $75 \%$ correct level for the threshold, while Williams used a $50 \%$ level.

McFadden, Barr, and Young (1971) used signal detection measures of sensitivity and found a $75 \%$ correct response at very low concentrations, 0.8 and $0.65 \mathrm{mM}$. Their procedure involved vigorous mouthrinsing, with distilled water rinses being 
expectorated immediately before tasting $\mathrm{NaCl}$ samples. The detection of such low $\mathrm{NaCl}$ concentrations is not surprising, considering that small changes in water purity can be detected given appropriate adaptation procedures (O'Mahony, 1972d).

Thus $\mathrm{NaCl}$ threshold studies in the literature tend to indicate that procedures involving a higher intake of water, whether by interstimulus rinsing or pair comparison, yield lower thresholds. This confirms the results of the present study. It is likely, then, that for in situ determinations, interstimulus procedures, especially rinsing vs no rinsing, are major determinants of the measured $\mathrm{NaCl}$ thresholds. In situ measures probably do little more than monitor the state of the saliva; constant-flow procedures, preferably using signal detection measures (O'Mahony, 1972c), would seem a desirable alternative. It is likely that these mouthrinsing effects reported for $\mathrm{NaCl}$ will be general for all stimuli that persist in the mouth.

\section{REFERENCES}

Anderson, C. D. The effect of subliminal salt solutions on taste thresholds. Journal of Comparative \& Physiological Psychology, 1955, 48, 164-166.

Bartosiuk, L. M. Water taste in man. Perception \& Psychophysics, 1968, 3, 69-72.

BÉKÉSY, G. von. The effect of adaptation on the taste threshold observed with a semiautomatic gustometer. Journal of General Physiology, 1965, 48, 481-488.

Blakeslee, A. F., \& Salmon, T. N. Genetics of sensory thresholds: Individual taste reactions for different substances. Proceedings of the National Academy of Sciences, 1935, 21, $84-90$.

Borg, G., Diamant, H., \& Zotterman, Y. Neural and perceptual responses to taste stimuli. In G. E. W. Wolstenholme and J. Knight (Eds.), Taste and smell in vertebrates. London: Churchill, 1970. Pp. 99-112.

BRown, W. The judgement of very weak sensory stimuli with special reference to the absolute threshold of sensation for common salt. University of California Publications in Psychology, 1914, 1, 199-268.

Bujas, Z. L'adaptation gustative et son mecanisme. Acta Instituti Psychologici Universitet Zabreb, 1953, 17, 1-10.

Camerer, W. Die Methode der richtigen und falschen Falle angewendet auf den Geschmackssinn. Zeitschrift für Biologie, $1885,21,570-602$.

Cooper, R. M., Bilash, I., \& Zubek, J. P. The effect of age on taste sensitivity. Journal of Gerontology, 1959, 14, 56-58.

Dallenbach, J. W., \& Dallenbach, K. M. The effects of bitteradaptation on sensitivity to other taste-qualities. American Journal of Psychology, 1943, 56, 21-31.

De Wardener, H. E., \& Herxheimer, A. The effect of a high water intake on salt consumption, taste thresholds and salivary secretion in man. Journal of Physiology, 1957, 139, 53-63.

Fabian, F. W., \& Blum, H. B. Relative taste potency of some basic food constituents and their competitive and compensatory action. Food Research, 1943, 8, 179-193.

Fallis, N., Lasagna, L., \& Tetreault, L. Gustatory thresholds in patients with hypertension. Nature, 1962, 196, 74-75.

Finkelstein, B., \& Pippitt, R. G. Effect of altitude and oxygen upon primary taste perception. Journal of Aviation Medicine, 1958, 29, 386-391.
Fischer, R., Griffin, F., \& Kaplan, A. R. Taste thresholds, cigarette smoking and food dislikes. Medicina Experimentalis, $1963,9,151-167$.

Frings, H. A contribution to the comparative physiology of contact chemoreception. Journal of Comparative \& Physiological Psychology, 1948, 41, 25-34.

Furchtgot, E., \& Willingham, W. W. The effect of sleep deprivation upon the thresholds of taste. American Journal of Psychology, 1956, 69, 111-112.

Furchtgott, E., \& Friedman, M. P. The effects of hunger on taste and odor RLs. Journal of Comparative \& Physiological Psychology, 1960, 53, 576-581.

GreEn, D. M., \& Swets, J. A. Signal detection theory and psychophysics. New York: Wiley, 1966.

Hahn. H. Die Adaptation des Geschmackssinnes. Zeitschrift für Sinnesphysiologie, 1934, 65, 105-145.

НАнN, Н. Beitrage zur Reizphysiologie. Heidelberg: Scherer Verlag. 1949.

Harries, J. M. Personality and sensory acuity. Agricultural Research Council (British): Meat Research Institute Memorandum, 1973, No. 23, 6 pp.

Harris, H., \& Kalmus, H. The measurement of taste sensitivity to phenylthiourea (PTC). Annals of Eugenics, 1949, 15, 24-31.

Henkin, R. I., \& Solomon. D. H. Salt-taste threshold in adrenal insufficiency in man. Journal of Clinical Endocrinology, 1962 , 22, 856-858.

Henkin, R. I., Gill, J. R., \& Bartter, F. C. Studies on taste thresholds in normal man and in patients with adrenal cortical insufficiency: The role of adrenal cortical steroids and of serum sodium concentration. Journal of Clinical Investigation, 1963, 42, 727-735.

Hermel, J., Schonwetter, S., \& Samueloff, S. Taste sensation and age in man. Journal of Oral Medicine, 1970, 25, 39-42.

Hopkins, J. W. Precision of assessment of palatability of foodstuffs by laboratory panels. Canadian Journal of Research, 1946, 24F, 203-214.

Hutchinson, W. R., \& Shiller, W. R. Taste thresholds in a submarine environment. U.S. Naval Submarine Medical Center Report, 1968, No. 530, 5 pp.

Irvin, D. L., \& GoetzL, F. R. Diurnal variations in acuity of sense of taste for sodium chloride. Proceedings of the Society of Experimental Biology \& Medicine, 1952, 79, 115-118.

JACKSON, J. A. Heavy smoking and sodium chloride hypogeusia. Journal of Dental Research, 1967, 46, 742-744.

JaNowitz, H. D., \& Grossman, M. I. Gusto-olfactory thresholds in relation to appetite and hunger sensations. Joumal of Applied Physiology, 1949, 2, 217-222.

KAHN, S. G. Taste perception-Individual reactions to different substances. Illinois Academy of Science Transactions, 1951, 44, 263-269.

Kalmus, H. Genetics of taste. In L. M. Beidler (Ed.), Handbook of sensory physiology. Vol. 4. Chemical senses. Part 2. Berlin: Springer-Verlag, 1971. Pp. 166-179.

KapUr, K. K., Collister, T., \& Fischer, E. E. Masticatory and gustatory salivary reflex section rates and taste thresholds of denture wearers. Journal of Prosthetic Dentistry, 1967, 18, 406-416.

Kel.rY, M. F., \& MAYER, J. Rapid determination of taste threshold: A group procedure. American Journal of Clinical Nutrition, 1971, 24, 177-180.

KING, F. B. Obtaining a panel for judging flavor in foods. Food Research, 1937, 2, 207-219.

Knowles, D., \& Johnson, P. E. A study of the sensitiveness of prospective food judges to the primary tastes. Food Research, 1941, 6, 207-216.

Krut, L. H., Perrin, M. J., \& Bronte-Stewart, B. Taste perception in smokers and non-smokers. British Medical Journal, 1961, 5223, 384.387.

Mackey, A. O., \& Jones, P. Selection of members of a food tasting panel: Discernment of primary tastes in water solution 
compared with judging ability for foods. Food Technology, 1954, 8, 527-530.

MAGA, J. A., \& LoRENz, K. Effect of altitute on taste thresholds. Perceptual \& Motor Skills, 1972, 34, 667-670.

MAYER, B. Messende Untersuchungen über die Umstimmung des Geschmackswerkzeugs. Zeitschrift für Simnesphysiologie, 1927, 58, 133-152.

MCBURney, D. H. A note on the relation between area and intensity in taste. Perception \& Psychophysics, 1969, 6, 250.

McBurney, D. H., \& Pfaffmann, C. Gustatory adaptation to salival and sodium chloride. Journal of Experimental Psychology, 1963, 65, 523-529.

McFadden, D.. Barr, E. A., \& Young, R. E. Audio analgesią: Lack of a cross-masking effect on taste. Perception \& Psychophisics, 1971, 10, 175-179.

MefFord, R. B., \& Wieland, B. A. Taste thresholds for sodium chloride in longitudinal experiments. Perceptual \& Motor Skills, 1968, 27, 295-315.

Meiselman, H. L. Magnitude estimations of the course of gustatory adaptation. Perception \& Psychophysics, 1968, 4, 193.196

MEYeR, D. R. The stability of human gustatory sensitivity during changes in time of food deprivation. Joumal of Comparative \& Phisiological Psychology. 1952, 45, 373-376.

Mosel. J. N., \& Kantrowitz, G. The effect of monosodium glutamate on acuity to the primary tastes. American Journal of Psychology', 1952, 65, 573-579.

O'MahonY, M. The interstimulus interval for taste: 1 . The efticiency of expectoration and mouthrinsing in clearing the mouth of salt residuals. Perception, 1972a, 1, 209-215.

O'Mahony, M. The interstimulus interval for taste: 2. Salt taste sensitivity drifts and the effects on intensity scaling and threshold measurement. Perception. 1972b, 1. 217-222.

O’MAHONY. M. Salt taste sensitivity: A signal detection approach. Percoption, 1972c, 1, 459-464.

O'MAHONY, M. Purity effects and distilled water taste. Nature, 1972d, 240, 489.

OMahony. M. Qualitative description of low concentration sodiun chloride solutions. British Journal of Psychology, 1973. 64. 60) 6 -606.

PANGBORN. R. M. Influence of hunger on sweetness preferences and taste thresholds. American Journal of Clinical Nutrition. 1959, 7, 280.287.

Pangborn, R. M. . Chrisp, R. B., \& Bertolero, L. L. Gustatory, salivary, and oral thermal responses to solutions of sodium chloride at four temperatures. Perception \& Psychophysics. $1970,8,69-75$.

Renovist, Y. Über den Geschmack. Skandinavisches Archir für Physiologie. 1919, 38, 97-201.

Richter, C. P.. \& Maclean, A. Salt taste thresholds of humans. American Jomrial of Physiology, 1939, 126, 1-6.

Schelling, J. L.. Tetreault, L., Lasagna, L.. \& Davis, M. Abnormat taste threshold in diabetes. Lancet, 1965, 1, 508-512.

Schutz, H. G., \& Pilgrim, F. J. Differential sensitivity to gustation. Journal of Experimental Psychology, 1957, 54, 41-48.

Topinka, I., \& Sova, J. Chutovy prah $\mathrm{NaCl}$, jeho geneticka vazba a mozny vyznan v etiologii hypertenze. Casopis Lekaru Ceskych, 1967, 106, 689-693.

UFLAND, J. M. Veranderungen der Geschmacksscharfe bei Bleiarbeitern. Zeitschrift fïr Sinnesphysiologie, 1928, 59, 128-135.

United States Department of Agriculture, Agricultural RESEARCH ADMINistration. Experimental procedure for conducting taste and smell tests. Mimeo, 1943, 8 pp.

WILLIAMs, R. A. Human detectability thresholds for saccharin, sodium saccharin, and sodium chloride. Journal of Comparative ¿ Physiological Psychology, 1970, 70, 113-115.

Wotman. S.. Mandel, 1. D., Khotim, S., Thompson, R. H., Kutscher, A. H.. Zegarelli, E. V., \& Denning, C. R. Salt taste thresholds and cystic fibrosis. American Journal of Diseases of Children, 1964, 108, 372-374.

Wotman, S., Mandel, I. D., Thompson, R. H., \& Laragh, J. H. Salivary electrolytes and salt taste thresholds in hypertension. Joumal of Chronic Diseases, 1967, 20, 833-840.

YENSEN, R. Influence of salt deficiency on taste sensitivity in human subjects. Nature, 1958, 181, 1472-1474.

YENSEN, R. Some factors affecting taste sensitivity in man, 1: Food intake and time of day. Quarterly Journal of Experimental Psychology, 1959a, 11, 221-229.

YeNSEN, R. Some factors affecting taste sensitivity in man, 2: Depletion of body salt. Quarterly Journal of Experimental Psychology, 1959b, 11, 230-238.

YENSEN, R. Some factors affecting taste sensitivity in man, 3: Water deprivation. Quarterly Journal of Experimental Psychol$\operatorname{og} v, 1959 \mathrm{c}, 11,239-248$.

YENSEN, R. Taste sensitivity and food deprivation, blood sugar level and composition of meal. Nature, 1964, 203, 327-328.

(Received for publication May 21, 1974; revision accepted July 4,1974 .) 